Article

\title{
Shifts in the Microbial Community of Activated Sludge with Different COD/N Ratios or Dissolved Oxygen Levels in Tibet, China
}

\author{
Jin $\mathrm{Xu}^{1,2}$, Peifang Wang ${ }^{1, *}, \mathrm{Yi} \mathrm{Li}^{1}{ }^{1 *}$, Lihua Niu ${ }^{1}$ and Zhen Xing ${ }^{2}$ \\ 1 Ministry of Education Key Laboratory of Integrated Regulation and Resource Development on Shallow \\ Lakes, College of Environment, Hohai University, Nanjing 210098, China; xurin123@163.com (J.X.); \\ nlhnq55@163.com (L.N.) \\ 2 College of Resources and Environment, Tibet Agricultural and Animal Husbandry University, \\ Tibet Nyingtri 860000, China; xztibetan@163.com \\ * Correspondence: pfwang2004@hotmail.com (P.W.); envly@hhu.edu.cn (Y.L.)
}

Received: 29 March 2019; Accepted: 12 April 2019; Published: 16 April 2019

\begin{abstract}
In this study, we examined the influence of the organic carbon-to-nitrogen ratio (chemical oxygen demand (COD/N)) and dissolved oxygen (DO) levels on the removal efficiency of pollutants and on the change in total microflora in the cyclic activated sludge system (CASS) in the Nyingchi prefecture in Tibet. The results demonstrated that the treatment performance was the best when the COD/ $\mathrm{N}$ ratio was 7:1 or the DO levels were $2-2.5 \mathrm{mg} / \mathrm{L}$ in comparison with four different tested COD/N ratios (4:1, 5:1, 7:1, and 10:1) and DO concentrations (0.5-1, 1-2, 2-2.5, and 2.5-3.5 mg/L). The treatment performance can be explained by the relative operational taxonomic unit richness and evenness of the microbial communities in activated sludge. Evident microbial variance was observed, especially different $\mathrm{COD} / \mathrm{N}$ ratios and $\mathrm{DO}$ concentrations, which were conducive to the disposal of urban sewage in plateaus. The results help to understand sewage treatment under different COD/N ratios or DO concentrations on plateaus. This work provides practical guidance for the operation of any wastewater treatment plant on a plateau.
\end{abstract}

Keywords: plateau; sewage treatment; $\mathrm{COD} / \mathrm{N}$ ratio; dissolved oxygen; microbial community

\section{Introduction}

Sewage treatment has contributed to the improvement in the water-environment in high-altitude regions [1]. The activated sludge method uses activated sludge to transform organic and inorganic pollutants, which has been applied to improve aquatic environments around the world. Due to its low operational cost and good performance (chemical oxygen demand (COD/N) removal efficiency can reach $85 \%$ or higher), it is still the most widely used and common water treatment measured in urban effluent treatment [2]. The wastewater treatment plants (WWTPs) at high-altitude regions face some operational barriers, mainly because of extreme climate conditions, such as thin air and low pressure [3]. The stable operation of WWTPs with widely-used sewage treatment technology, based on the activated sludge or biological process in plateau regions, is crucial [1].

The main factors influencing urban effluent treatment processes include the $\mathrm{COD} / \mathrm{N}$ ratio and the dissolved oxygen (DO) concentration. If the COD/N ratio in influent concentration is too high, heterotrophic organisms consume more available ammonia-nitrogen than nitrifying organisms [4]. Yun [5] stated that nitration activity gradually fails at the reactors with organic additions. Sharma [6] reported that the nitrification rate increases with deduced COD/TKN (Kjeldahl nitrogen) in the influent. Luo et al. [7] studied the effect of the COD/N ratio in influent on the decomposition of aerobic granule sludge, and the results showed that when the COD/N ratio in the influent is 2:1 or 1:1, it strongly 
influenced the stability of aerobic granule sludge with regard to physical properties and nitrification efficiency, and when the COD/ $\mathrm{N}$ ratio is reduced to 1:1, the aerobic granule sludge decomposes. Since an increased $\mathrm{COD} / \mathrm{N}$ could result in a lowered nitrification efficiency and enhanced denitrification efficiency, the COD/N ratio in influent influences the quantity of microorganisms [8]. Zielinska [9] studied nitrogen removal from wastewater and the bacterial diversity of activated sludge at different $\mathrm{COD} / \mathrm{N}$ ratios and $\mathrm{DO}$ concentrations. The results showed that the total bacteria diversity was similar in all experimental series and the diversity and abundance of ammonia-oxidizing bacteria (AOB) were higher in the reactors with a $\mathrm{COD} / \mathrm{N}$ ratio of $0.7: 1$ in comparison with the reactors with a $\mathrm{COD} / \mathrm{N}$ of 6.8:1 [9].

In any urban WWTP, the DO concentration determines the degradation rate of organic matter in microflora, aerobic growth, and the operational cost $[10,11]$. DO concentrations must be controlled because it determines the dominant reaction process in the reactor. High DO concentrations suppress denitrification, and low DO concentrations lead to restricted ammoxidation [12]. Dissolved oxygen can be controlled by air supply, so the cost of treating wastewater with oxygen is affected. A low $\mathrm{COD} / \mathrm{N}$ ratio and $\mathrm{DO}$ concentration facilitate a nitrification effect to some extent and decrease oxygen demand by $25 \%$ and COD by $40 \%$ in the denitrification process $[13,14]$. According to the report by $\mathrm{Ma}$ [15], in the continuous flow system of domestic urban wastewater treatment, $0.4-0.7 \mathrm{mg} / \mathrm{L}$ DO was conducive to nitrite accumulation. Yadav [16] evaluated the microbial community in response to different DO concentrations $(1,2$, and $4 \mathrm{mg} / \mathrm{L})$ in activated sludge and the results showed that the diversity of bacteria was the greatest when the DO was $2 \mathrm{mg} / \mathrm{L}$ in the reactor. The pressure increases in the gas phase and the concentration of saturated DO increases in the water, which is conducive to the oxygen transfer to the water, whereas the pressure decreases when the sewage is aerated in the biological treatment tank. The oxygen pressure at $4000 \mathrm{~m}$ altitude is only $60 \%$ of that at sea level [3]. Oxygen transfer varies due to variation in pressure and its influence on microbial communities at high latitudes. Therefore, we need more information on the microbial community of activated sludge with different DO levels at high latitudes.

Many studies have provided information about low-elevation WWTPs. To provide some practical guidance on domestic wastewater treatment in plateau regions, the objectives of this study were: (1) To investigate the influence of different $\mathrm{COD} / \mathrm{N}$ ratios or $\mathrm{DO}$ concentrations on urban wastewater treatment on plateaus, (2) to investigate microbial community structure and its diversity in activated sludge under different $\mathrm{COD} / \mathrm{N}$ ratios or $\mathrm{DO}$ concentrations in plateaus, and (3) to determine the relationships amongst domestic wastewater treatment performance, microflora structure, and species diversity. We think these results provide practical guidance for treating domestic wastewater in plateau regions.

\section{Materials and Methods}

\subsection{Reactor and Operation}

A total of four lab-scale cyclic activated sludge systems (CASSs) were used to treat synthetic sewage in Nyingtri, Tibet. The experimental site, the Environmental Science and Engineering Laboratory of the Tibet Agricultural and Animal Husbandry University, was located at an altitude of about $3000 \mathrm{~m}$ above sea level. The atmospheric pressure of the experimental site was $706 \mathrm{hPa}$ (measured value). A schematic diagram of the CASS reactor and the reactor volume of $0.045 \mathrm{~m}^{3}$ are shown in Figure 1. Activated sludge (AS) originated from the Lhasa sewage treatment plant with an initial sludge concentration of $2.5 \mathrm{~g} / \mathrm{L}$. The synthetic influent sewage feed and the aeration system of the device were adjusted by a creep pump. The $\mathrm{pH}$ in the system was maintained between 7.2 and 8.4. The $\mathrm{pH}$ was adjusted with anhydrous sodium carbonate. The reactor was run under water temperature $\left(11 \pm 1^{\circ} \mathrm{C}\right)$. The composition of the synthetic sewage is shown in Table 1 at different $\mathrm{COD} / \mathrm{N}$ ratios test stages. $\mathrm{CN}-1, \mathrm{CN}-2, \mathrm{CN}-3$, and $\mathrm{CN}-4$ refer to the $\mathrm{COD} / \mathrm{N}$ ratios of $4: 1,5: 1,7: 1$, and 10:1, respectively. The DO was kept constant, or more than $4 \mathrm{mg} / \mathrm{L}$, to provide adequate oxygen during the different 
$\mathrm{COD} / \mathrm{N}$ ratios test stages. The composition of the synthetic sewage is shown in Table 2 at different DO concentration test stages. DO-1, DO-2, DO-3, and DO-4 refer to the DO concentrations of 0.5-1, $1-2,2-2.5$, and $2.5-3.5 \mathrm{mg} / \mathrm{L}$, respectively. The $\mathrm{COD} / \mathrm{N}$ ratio was controlled at 7:1 to provide adequate nutrients during the different $\mathrm{DO}$ concentration test stages. Under batch feeding conditions, there were four daily CASS cycles. One CASS operational cycle required $6 \mathrm{~h}$, of which $4 \mathrm{~h}$ were the aeration stage, and $2 \mathrm{~h}$ were the sludge setting and drainage stage.

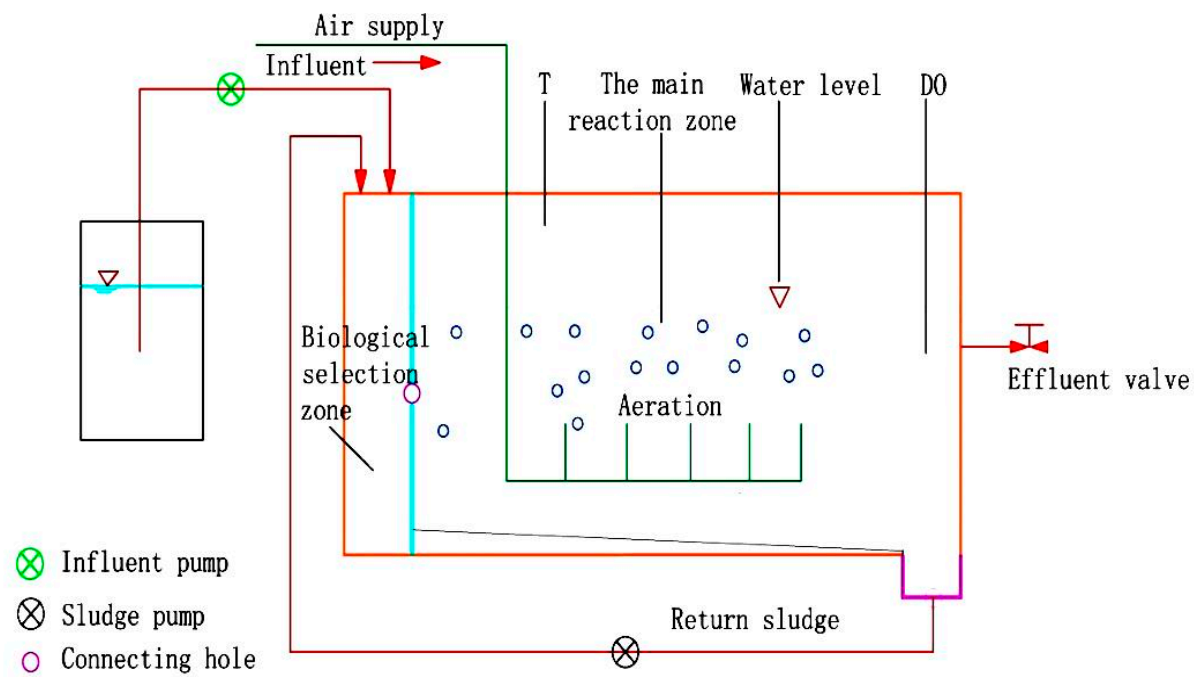

Figure 1. The cyclic activated sludge system (CASS) process unit.

Table 1. The composition of synthetic sewage (chemical oxygen demand (COD/N), $\mathrm{H}_{4}{ }^{+}-\mathrm{N}=4 / 1,5 / 1$, $7 / 1$ and $10 / 1)$.

\begin{tabular}{cccc}
\hline Species & Composition & Concentration $(\mathbf{m g} / \mathrm{L})$ & Confect \\
\hline Organics & $\mathrm{COD}$ & $120,150,210,300$ & glucose \\
Nitrogen compounds & $\mathrm{NH}_{4}^{+}-\mathrm{N}$ & 30 & $\mathrm{NH}_{4} \mathrm{CI}$ \\
Phosphorus compounds & $\mathrm{TP}$ & 5 & $\mathrm{~K}_{2} \mathrm{HPO}_{4}$ \\
\hline \multirow{2}{*}{ Other additions and } & $\mathrm{MgSO}_{4} \cdot 7 \mathrm{H}_{2} \mathrm{O}(12) ; \mathrm{FeSO}_{4} \cdot 7 \mathrm{H}_{2} \mathrm{O}(10) ; \mathrm{CaCl}_{2}(30) ; \mathrm{NaHCO}_{3}(50) ; \mathrm{pH}(7.2-8.4) ;$ \\
trace elements $(\mathrm{mg} / \mathrm{L})$ & $\mathrm{H}_{3} \mathrm{BO}_{3}(0.15) ; \mathrm{CoCl}_{2} \cdot 6 \mathrm{H}_{2} \mathrm{O}(0.15) ; \mathrm{CuSO}_{4} \cdot 6 \mathrm{H}_{2} \mathrm{O}(0.03) ; \mathrm{FeCl}_{3} \cdot 6 \mathrm{H}_{2} \mathrm{O}(1.5) ; \mathrm{KI}(0.03) ;$ \\
& $\mathrm{MnCl}_{2} \cdot 2 \mathrm{H}_{2} \mathrm{O}(0.12) ;\left(\mathrm{NH}_{4}\right)_{2} \mathrm{Mo}_{7} \mathrm{O}_{24} \cdot 2 \mathrm{H} \mathrm{H}_{2} \mathrm{O}(0.06) ; \mathrm{ZnSO}_{4} \cdot 7 \mathrm{H}_{2} \mathrm{O}(0.12)$ \\
\hline
\end{tabular}

Table 2. The composition of synthetic sewage (dissolved oxygen $(\mathrm{DO})=0.5-1,1-2,2-2.5$ and $2.5-3.5 \mathrm{mg} / \mathrm{L})$.

\begin{tabular}{cccc}
\hline Species & Composition & Concentration $(\mathbf{m g} / \mathrm{L})$ & Confect \\
\hline Organics & $\mathrm{COD}$ & 210 & glucose \\
Nitrogen compounds & $\mathrm{NH}_{4}^{+}-\mathrm{N}$ & 30 & $\mathrm{NH}_{4} \mathrm{CI}$ \\
Phosphorus compounds & $\mathrm{TP}$ & 5 & $\mathrm{~K}_{2} \mathrm{HPO}_{4}$ \\
\hline \multirow{2}{*}{ Other additions and } & $\mathrm{MgSO}_{4} \cdot 7 \mathrm{H}_{2} \mathrm{O}(12) ; \mathrm{FeSO}_{4} \cdot 7 \mathrm{H}_{2} \mathrm{O}(10) ; \mathrm{CaCl}_{2}(30) ; \mathrm{NaHCO}_{3}(50) ; \mathrm{pH}(7.2-8.4) ;$ \\
trace elements $(\mathrm{mg} / \mathrm{L})$ & $\mathrm{H}_{3} \mathrm{BO}_{3}(0.15) ; \mathrm{CoCl}_{2} \cdot 6 \mathrm{H}_{2} \mathrm{O}(0.15) ; \mathrm{CuSO}_{4} \cdot 6 \mathrm{H}_{2} \mathrm{O}(0.03) ; \mathrm{FeCl}_{3} \cdot 6 \mathrm{H}_{2} \mathrm{O}(1.5) ; \mathrm{KI}(0.03) ;$ \\
& $\mathrm{MnCl}_{2} \cdot 2 \mathrm{H}_{2} \mathrm{O}(0.12) ;\left(\mathrm{NH}_{4}\right)_{2} \mathrm{Mo}_{7} \mathrm{O}_{24} \cdot 2 \mathrm{H} \mathrm{H}_{2} \mathrm{O}(0.06) ; \mathrm{ZnSO}_{4} \cdot 7 \mathrm{H}_{2} \mathrm{O}(0.12)$ \\
\hline
\end{tabular}

To describe "cyclical", a decanting factor $\left(\mathrm{F}_{\mathrm{d}}\right)$ can be obtained: $\mathrm{F}_{\mathrm{d}}=\mathrm{V}_{\mathrm{e}} / \mathrm{V}_{\mathrm{d}}$,

Where $V_{e}$ is $10 \mathrm{~L}$ wastewater that was exchanged in each cycle, $V_{d}$ is the reactor volume, $0.045 \mathrm{~m}^{3}$. The reactors ran continuously for about 25 days, including 10 days of adjustment and 15 days of stabilization. 


\subsection{Collection of Samples and Analytical Methods}

Daily measurements of the effluent of the reactors included: $\mathrm{COD}, \mathrm{NH}_{4}-\mathrm{N}^{+}, \mathrm{NO}_{2}{ }^{-}-\mathrm{N}, \mathrm{NO}_{3}{ }^{-}-\mathrm{N}$, and total phosphorus (TP), according to Chinese standard methods during the stable stage [17]. COD was determined using the potassium dichromate method. Nitrogen content was measured with a flow analyzer. TP was determined by ammonium molybdate spectrophotometry. A portable dissolved oxygen meter (JPBJ-608, Shanghai Precision and Scientific Instrument Corporation, Shanghai, China) was used to determine the water temperature and DO. We collected $10 \mathrm{~mL}$ of the mixed liquor-suspended solids (MLSS) reaction mixture from each reactor during the stable stage for microbiological analysis.

\subsection{Pyrosequencing Analysis}

The microbial community structure and its diversity of activated sludge samples were investigated by high-throughput $16 \mathrm{~S}$ ribosomal ribonucleic acid (rRNA) gene sequencing. The detailed operational steps of the pyrosequencing methods have been described by $\mathrm{Xu}$ [18]. The rarefaction analysis was conducted to reveal the diversity indices. The detailed data processing and analysis have also been described by $\mathrm{Xu}[19]$.

\section{Results and Discussion}

\subsection{Richness and Evenness of Microbial Communities of Activated Sludge}

The relative operational taxonomic unit (OTU) richness and evenness of microbial communities of activated sludge with different $\mathrm{COD} / \mathrm{N}$ ratios or $\mathrm{DO}$ concentrations are shown in Figures $2-4$. The relative OTU richness of the species is reflected in the length of the curve on the horizontal axis. The wider the curve, the richer the relative OTU richness of the species. The relative OTU evenness of species composition is reflected in the shape of the curve. The flatter the curve, the more relative the OTU evenness of species composition. The relative OTU richness and evenness of the bacterial communities occurred when the COD/N ratio was 7:1 or the DO was $2-2.5 \mathrm{mg} / \mathrm{L}$ (Figure 2). The relative OTU richness and evenness of the fungal communities of activated sludge peaked at a COD/N ratio of $5: 1$ or DO of $2-2.5 \mathrm{mg} / \mathrm{L}$ (Figure 3). The relative OTU richness and evenness of archaeal communities were the highest, at the COD/N ratio of 7:1 or the DO of 2-2.5 mg/L (Figure 4). The Shannon index values for different $\mathrm{COD} / \mathrm{N}$ ratios and $\mathrm{DO}$ concentrations are shown in Table 3 . The Shannon index values represent the diversity and evenness of a sample. Table 3 shows that the diversity and evenness of fungal communities of activated sludge were far lower at COD/N of 4:1, 7:1, and 10:1 than that at 5:1. The diversity and evenness of fungal communities of activated sludge were far lower at the DO of $0.5-1,1-2$, and $2.5-3.5 \mathrm{mg} / \mathrm{L}$ than at $2-2.5 \mathrm{mg} / \mathrm{L}$. As shown in Figure 3, the broken curve ends at the lower horizontal axis values. The highest species diversity and evenness was observed when the $\mathrm{COD} / \mathrm{N}$ ratio was $7: 1$ or the $\mathrm{DO}$ was $2-2.5 \mathrm{mg} / \mathrm{L}$.

Table 3. The Shannon index values with different $\mathrm{COD} / \mathrm{N}$ ratios or $\mathrm{DO}$ concentrations.

\begin{tabular}{ccccccccc}
\hline Shannon Index & $\mathbf{C N - 1}$ & $\mathbf{C N}-2$ & $\mathbf{C N}-3$ & $\mathbf{C N}-4$ & DO-1 & DO-2 & DO-3 & DO-4 \\
\hline bacterial & 2.27 & 1.93 & 3.29 & 2.39 & 2.62 & 3.23 & 3.37 & 2.61 \\
fungal & 1.26 & 2.53 & 1.10 & 1.52 & 0.13 & 0.38 & 1.13 & 0.38 \\
archaeal & 2.21 & 2.22 & 3.38 & 2.17 & 3.05 & 3.06 & 3.37 & 2.87 \\
\hline
\end{tabular}



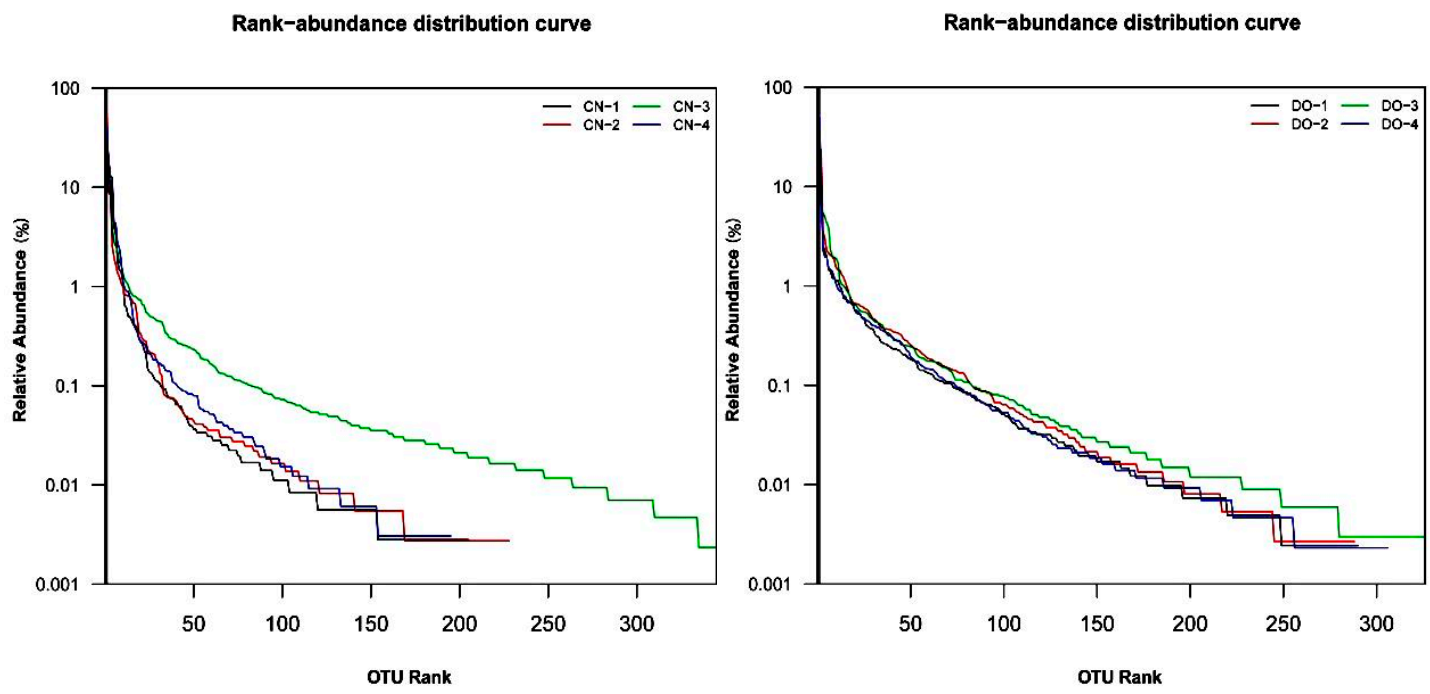

Figure 2. Relative abundance of the operational taxonomic unit () richness and evenness of bacterial communities of activated sludge.
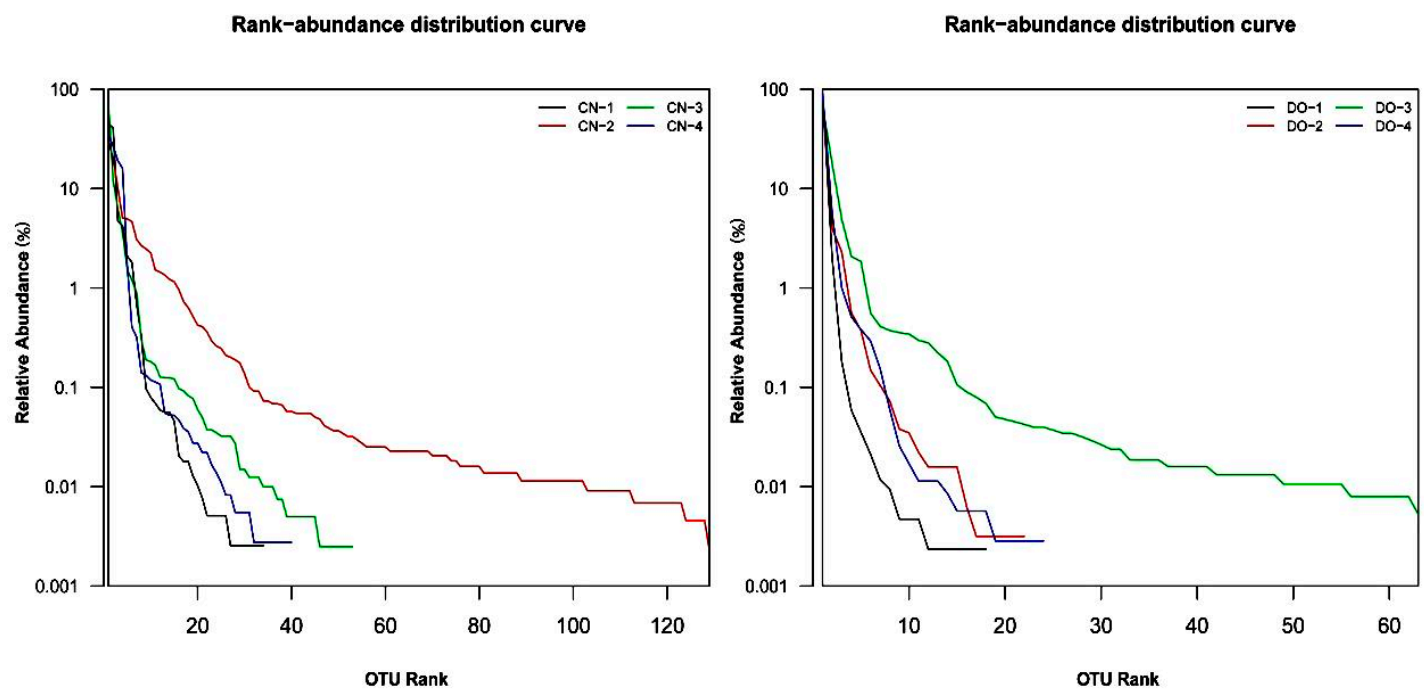

Figure 3. Relative abundance of the OTU richness and evenness of fungal communities of activated sludge.
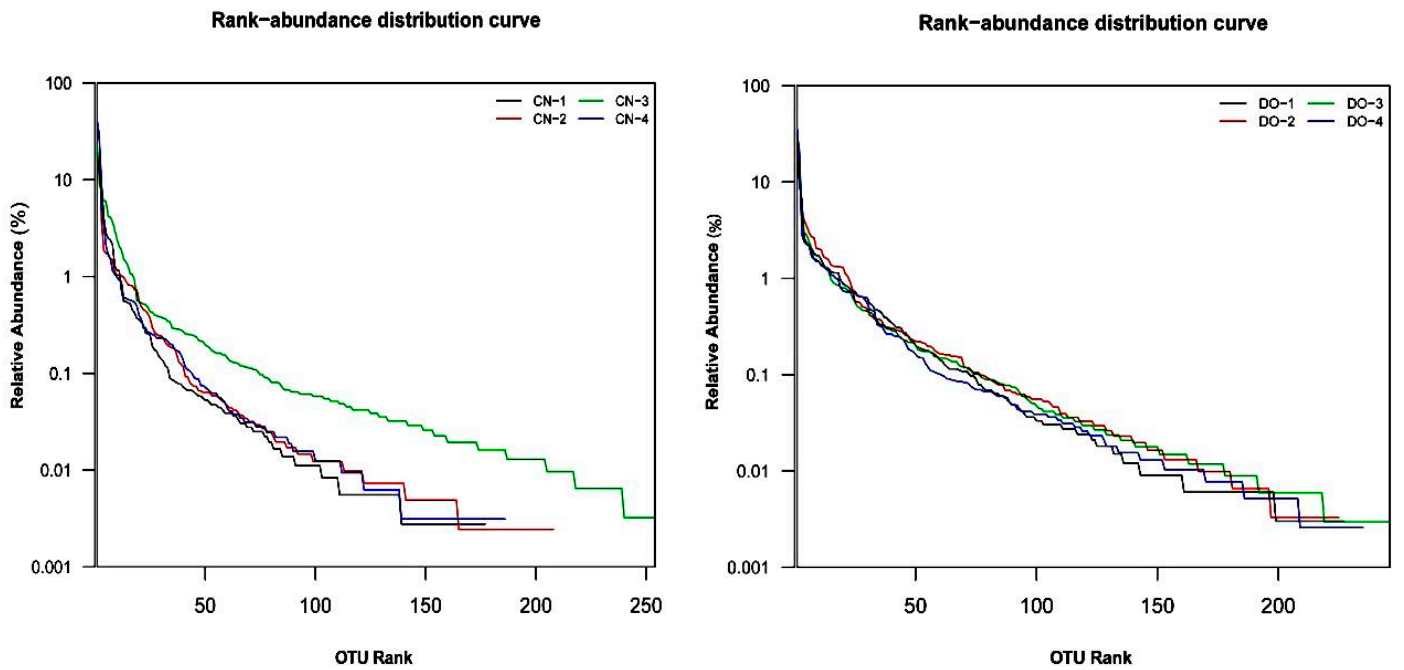

Figure 4. Relative abundance of the OTU richness and evenness of archaeal communities of activated sludge. 


\subsection{Microbial Community Structures}

Figure 5 depicts the relative abundance of the bacterial community under different COD/N ratios or DO concentrations in the activated sludge. The results indicate that Proteobacteria $(>80 \%)$ was the main group in the activated sludge and Bacteroidetes $(<10 \%)$ was secondary in activated sludge when the $\mathrm{COD} / \mathrm{N}$ ratio was $4: 1$ and $5: 1$. When the $\mathrm{COD} / \mathrm{N}$ ratio was $7: 1$, Proteobacteria (43.51\%) was the main group and Bacteroidetes (37.88\%) was the secondary group in activated sludge. When the COD/ $\mathrm{N}$ ratio was 10:1, Proteobacteria (68.38\%) was the main group and Bacteroidetes $(14.19 \%)$ was the secondary group in activated sludge. These figures demonstrate that Proteobacteria was sensitive to the COD/N ratio. As shown in Figure 5, under different COD/N ratios, Proteobacteria was the most abundant phylum and Bacteroidetes was the second most abundant phylum in activated sludge. This result is similar to reported research results for urban WWTPs $[20,21]$. The previous research revealed that some Actinobacteria, Bacteroidetes, and Firmicutes members can decompose complex polysaccharides [22,23]. When the COD/N ratio was 10:1, the proportion of Actinobacteria increased to $15.39 \%$. As shown in Figure 5, the relative abundance of the Actinobacteria was lower at the COD/N ratios of 4:1, 5:1, and 7:1 than at 10:1. Actinobacteria play a necessary role in nutrient removal during sewage treatment [24]. The microbial abundance at the phylum level was lower at COD/N ratios of 4:1, 5:1, and 10:1 than at 7 , indicating that the proportions of different phyla in the bio-community in the sludge vary with the feeding ratio.
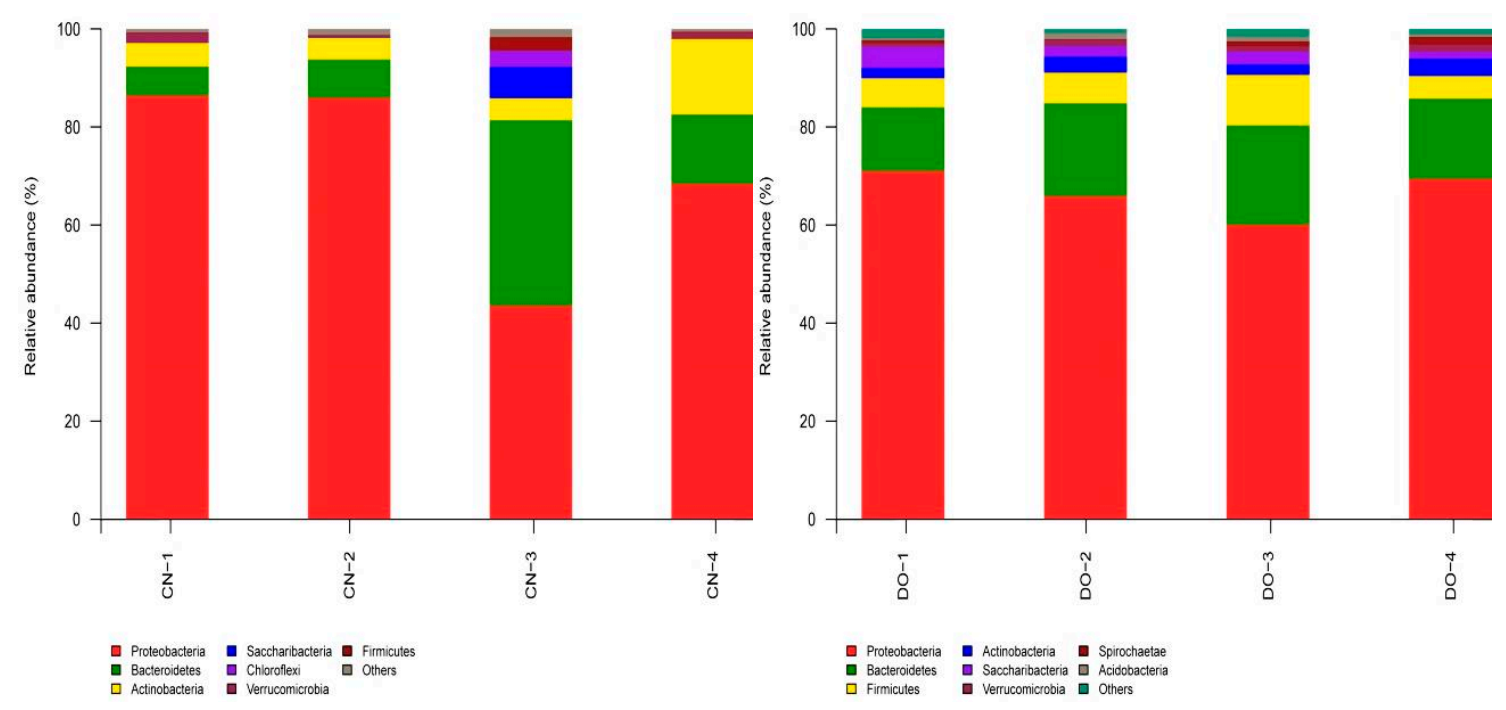

Figure 5. Relative abundance of bacterial phyla of activated sludge.

As shown in Figure 5, when the DO concentrations were 0.5-1, 1-2, 2-2.5, and 2.5-3.5 mg/L, Proteobacteria $(>60 \%)$ was the main group in activated sludge. Under different DO concentrations, Proteobacteria was the most abundant phylum. When the DO concentration was $2-2.5 \mathrm{mg} / \mathrm{L}$, Firmicutes $(10.29 \%)$ was significantly augmented. The relative abundance of Firmicutes was lower when the DO concentration was $0.5-1,1-2$, and $2.5-3.5 \mathrm{mg} / \mathrm{L}(5.89 \%, 6.23 \%$, and $4.60 \%$, respectively) than that at $2-2.5 \mathrm{mg} / \mathrm{L}(10.29 \%)$. In this research, the majority of sequences were labelled as unclassified, and the most abundant phylum observed in all reactors and the previously activated biomass, such as Actinobacteria, Proteobacteria, Firmicutes, Bacteroidetes, Acidobacteria, Nitrospira, and Chloroflexi, were previously reported $[25,26]$. This result is similar to previous research results [16]. The difference in our reported richness and evenness of microbial community to those reported by Chandra Yadav et al. [16] may be related to elevational gradient. As reported by Niu [27], a significant change in the evenness of the bacterial community was observed at around $1200 \mathrm{~m}$ of elevation with a linear decline as elevation increased to $3660 \mathrm{~m}$. The microbial abundance at the phylum level was clearly lower when the DO concentration was $0.5-1,1-2$, and $2.5-3.5 \mathrm{mg} / \mathrm{L}$ than 
when the DO was $2-2.5 \mathrm{mg} / \mathrm{L}$, indicating that the bio-community proportions in the sludge vary with the DO concentration.

Figure 6 summarizes the relative abundances of the fungi community on the phylum level of activated sludge with different $\mathrm{COD} / \mathrm{N}$ ratios or DO concentrations. The figure shows that Ascomycota was the most abundant phylum. Basidiomycota was the second most abundant phylum, followed by unclassified fungi when the COD/N ratio was at 4:1, 5:1, 7:1, or 10:1. Ascomycota (81.38\%) was predominant and Basidiomycota $(17.50 \%)$ was also a major group when the $\mathrm{COD} / \mathrm{N}$ ratio was at 7 . Ascomycota also played a critical role in nutrient removal during sewage treatment. As shown in Figure 6, Basidiomycota $(>70 \%)$ was predominant, followed by Ascomycota $(<30 \%)$ in activated sludge, when the DO was at $0.5-1,1-2,2-2.5$, or 2.5-3.5 mg/L. In Figure 6, the relative abundances of Ascomycota at the DO of $0.5-1,1-2$, and $2.5-3.5 \mathrm{mg} / \mathrm{L}(2.04 \%, 4.58 \%$, and $7.21 \%$, respectively) were lower than when the DO was $2-2.5 \mathrm{mg} / \mathrm{L}(23.81 \%)$.
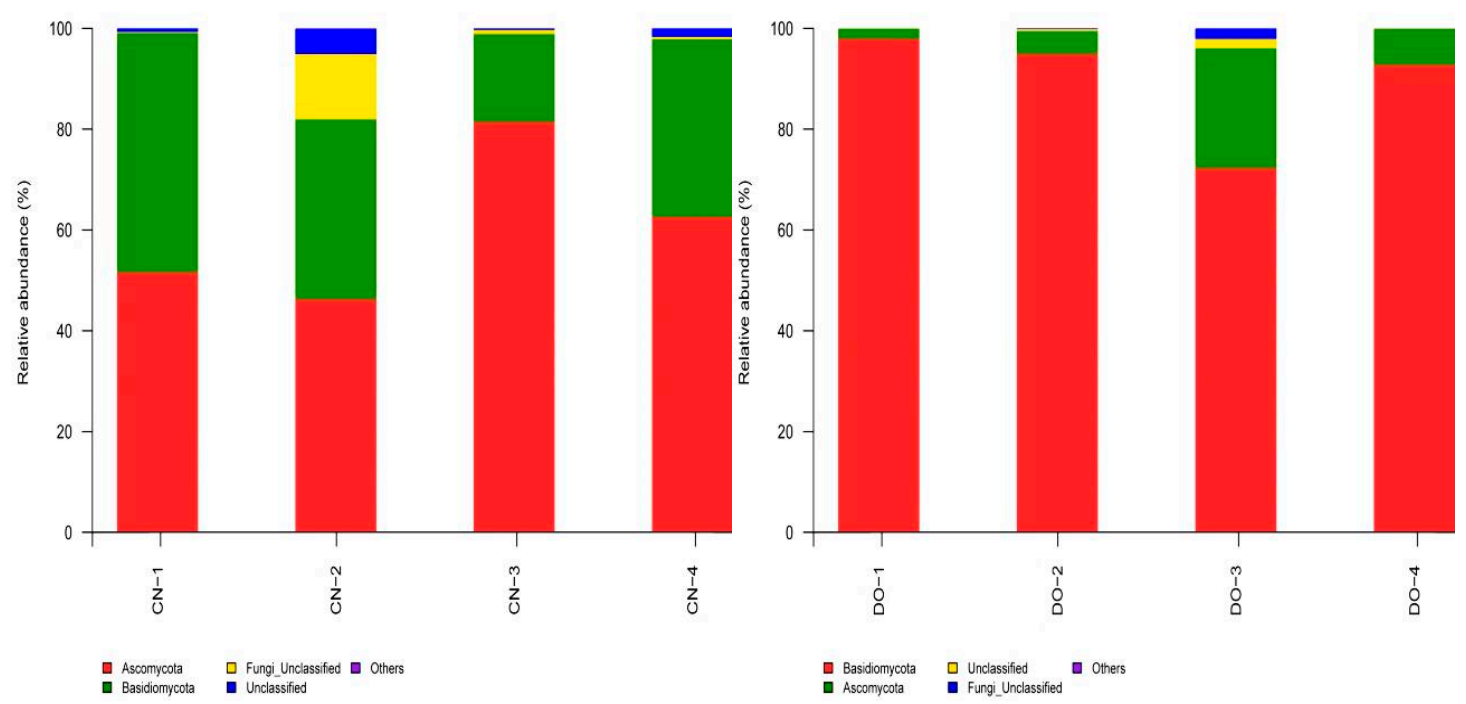

Figure 6. Relative abundance of fungal phyla of activated sludge.

Figure 7 demonstrates the relative abundances of the archaeal community on the phylum level of activated sludge at different $\mathrm{COD} / \mathrm{N}$ ratios or $\mathrm{DO}$ concentrations. Figure 7 show that Thaumarchaeota represented the most abundant phylum. Euryarchaeota was the second most abundant phylum, followed by Bacteroidetes when the COD/N ratio was 4:1 and 5:1. Bacteroidetes was the most abundant phylum, Euryarchaeota was the second most abundant phylum, followed by Thaumarchaeota when the COD/N ratio was 7:1. Euryarchaeota was the most abundant phylum, Thaumarchaeota was the second most abundant phylum, followed by Bacteroidetes when the COD/N ratio was 10:1. Figure 7 suggests that Euryarchaeota was sensitive to the COD/N ratio. Thaumarchaeota $(>50 \%)$ was predominant, and Euryarchaeota $(<40 \%)$ was also a major group in activated sludge when the DO was $0.5-1,1-2$, 2-2.5, and 2.5-3.5 mg/L. The relative abundances of Euryarchaeota when the DO was 0.5-1, 1-2, and $2.5-3.5 \mathrm{mg} / \mathrm{L}(18.89 \%, 24.77 \%$, and $26.22 \%$, respectively) were lower than when the DO was $2-2.5 \mathrm{mg} / \mathrm{L}(39.82 \%)$. These results demonstrate that shifts in microbial community occur with different $\mathrm{COD} / \mathrm{N}$ ratios or $\mathrm{DO}$ concentrations. 

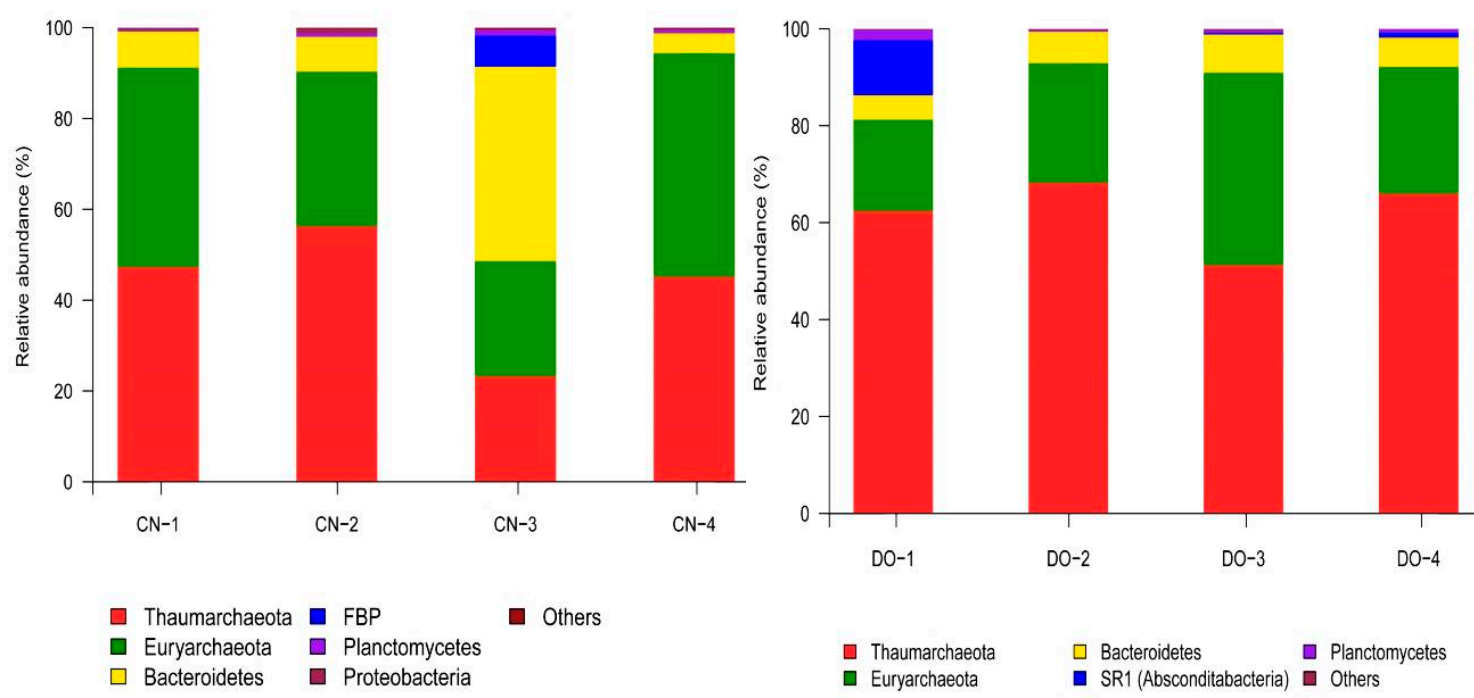

Figure 7. Relative abundance of archaeal phyla of activated sludge.

\subsection{Process Performance}

The COD/N ratio in domestic sanitary wastewater is normally lower than these specified values, where the removal of nitrogen was restricted by the lack of organic carbon sources [28]. When the $\mathrm{COD} / \mathrm{TN}$ (Total Nitrogen) ratio in influent concentration was less than four, removing the nitrogen was difficult $[29,30]$. Carbon shortage was detrimental to denitrification [31]. Figure 8 demonstrates the removal result of carbon, nitrogen, and phosphorus under different $\mathrm{COD} / \mathrm{N}$ ratios. Figure 8 shows that the removal rate of COD and TP was the highest when the COD/N ratio was 7:1. The average removal rate of COD and TP was about $81 \%$ and $66 \%$, respectively, when the COD/N ratio was 7:1. A lack of nutrients in the aerobic tank or excessive sludge load could lead to sludge disintegration.

Figure 8 shows that, in every reactor, the ammonia-nitrogen concentration in effluent did not exceed $4 \mathrm{mg} / \mathrm{L}$, and nitrites and nitrates were the main nitrogen oxide form. The $\mathrm{NO}_{3}{ }^{-}-\mathrm{N}$ and $\mathrm{NO}_{2}{ }^{-}-\mathrm{N}$ concentrations in the effluent gradually increased in the stable stage. In the stable stage, the accumulated $\mathrm{NO}_{3}{ }^{-}-\mathrm{N}$ and $\mathrm{NO}_{2}{ }^{-}-\mathrm{N}$ concentrations were $19.28,19.19,19.36$, and $19.04 \mathrm{mg} / \mathrm{L}$ when the COD/N ratio was 4:1, 5:1, 7:1, and 10:1, respectively. As shown in Figure 8, the effluent $\mathrm{NH}_{4}-\mathrm{N}^{+}$ (average $2.38 \mathrm{mg} / \mathrm{L}$ ) at a COD/N ratio of 7:1 were lower than when the COD/N ratio was 4:1 $(2.59 \mathrm{mg} / \mathrm{L})$, $5: 1(2.67 \mathrm{mg} / \mathrm{L})$, and 10:1 $(2.64 \mathrm{mg} / \mathrm{L})$. In this batch of experiments, the ammonia oxidation efficiency exceeded $89 \%$, with nitrites and nitrates as the main products. The treatment performance was the best when the $\mathrm{COD} / \mathrm{N}$ ratio was 7:1, compared with all tested $\mathrm{COD} / \mathrm{N}$ ratios.
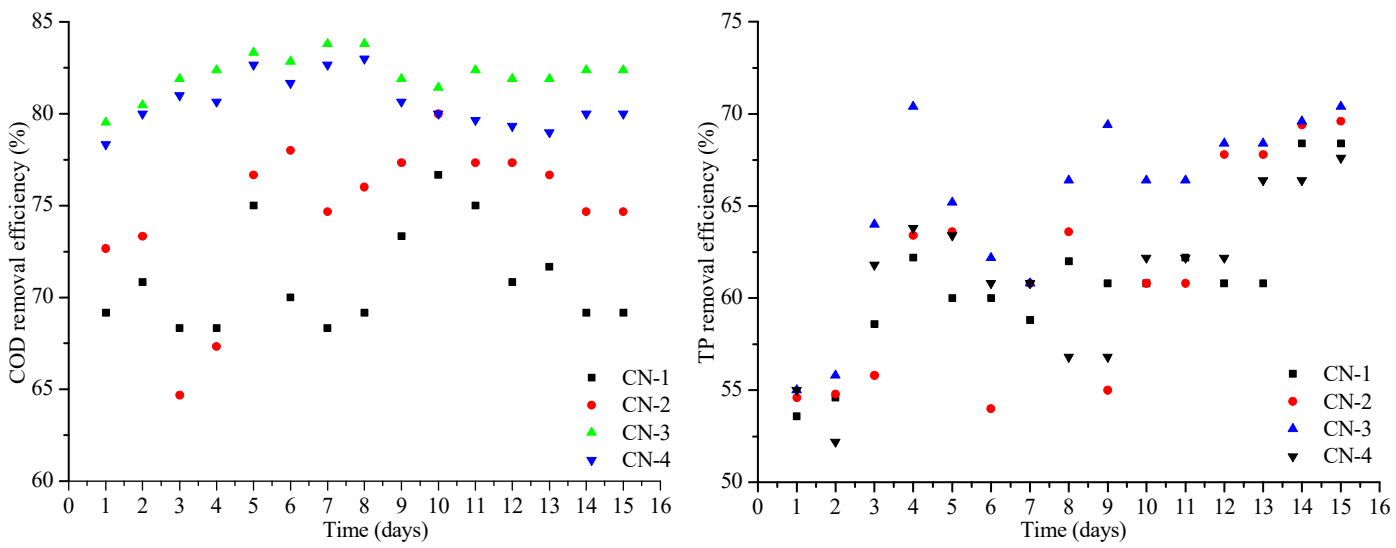

Figure 8. Cont. 

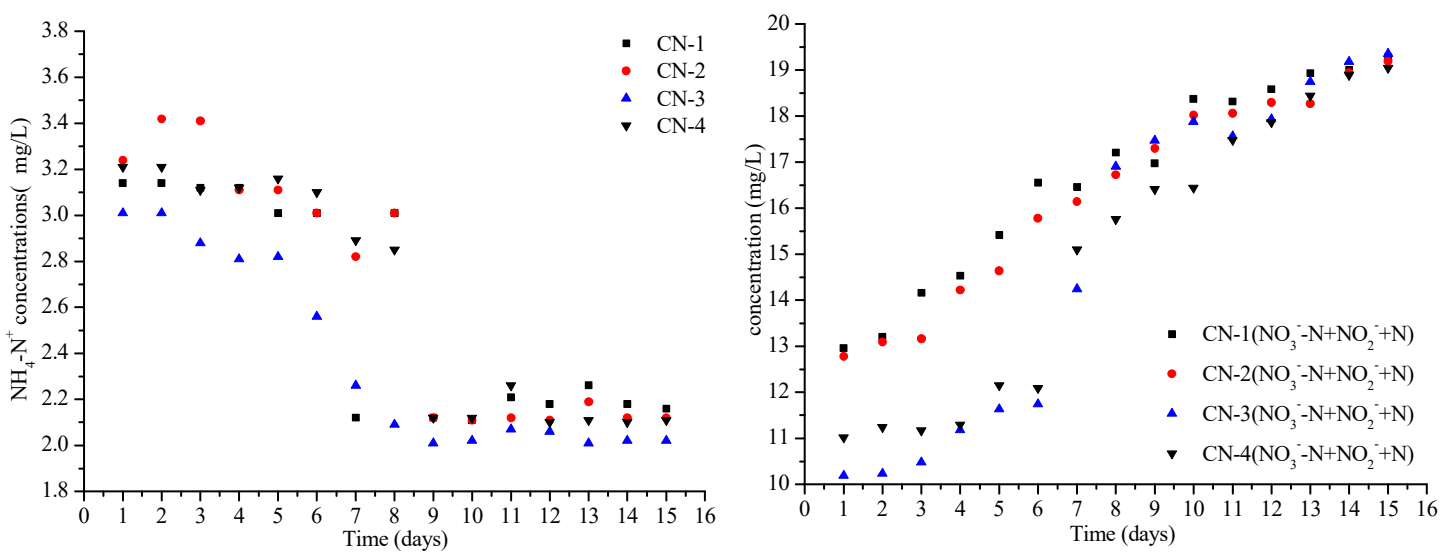

Figure 8. The effluent parameter $\mathrm{NH}_{4}-\mathrm{N}^{+}, \mathrm{NO}_{3}{ }^{-}-\mathrm{N}$, and $\mathrm{NO}_{2}{ }^{-}-\mathrm{N}, \mathrm{COD}$ and total phosphorus (TP) removal efficiency under different $\mathrm{COD} / \mathrm{N}$ ratios.

Figure 9 demonstrates the removal result of carbon, nitrogen, and phosphorus under different DO concentrations. The water quality blackened for a long time in the aerobic pond due to lack of oxygen. The figure shows that the COD degradative efficiency was the lowest when operating at 0.5-1 $\mathrm{mg} / \mathrm{L}$. Operation at 2-2.5 mg/L DO produced the highest COD removal rates throughout the 15-day stabilization period of the study. The average removal rates of COD and TP were about $83 \%$ and $75 \%$, respectively, when the DO was $2-2.5 \mathrm{mg} / \mathrm{L}$. High DO concentration lead to the oxidation and disintegration of sludge. It was easier to sediment active sludge as a result of degassing.
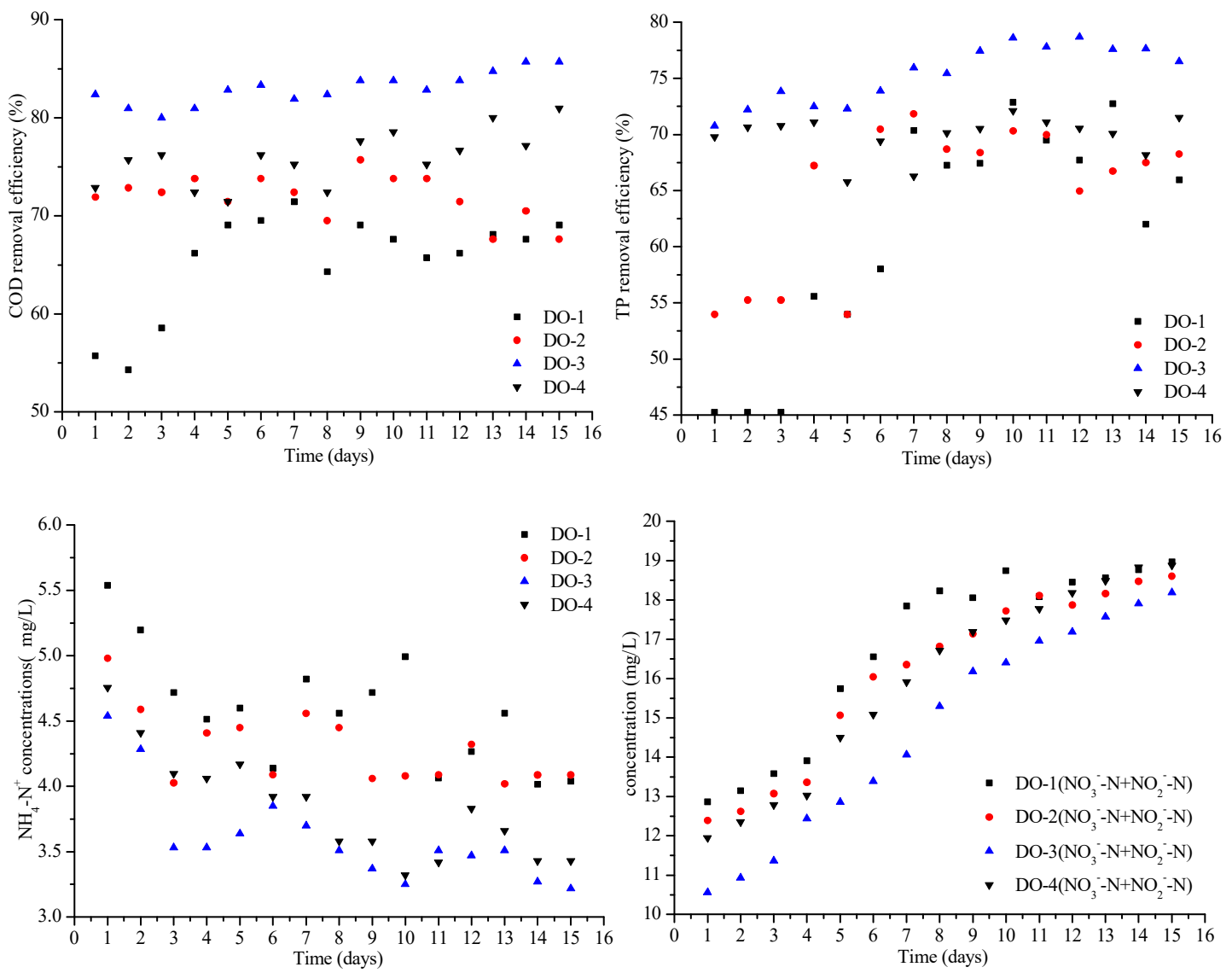

Figure 9. The effluent parameter, $\mathrm{NH}_{4}-\mathrm{N}^{+}, \mathrm{NO}_{3}{ }^{-}-\mathrm{N}$, and $\mathrm{NO}_{2}{ }^{-}-\mathrm{N}, \mathrm{COD}$, and TP removal efficiency under different DO concentrations. 
The nitrogen content in wastewater was also important as it not only caused eutrophication of a water body, but excessive ammonia in wastewater affected the degradation capacity and microbial growth [32-34]. In every reactor, the ammonia-nitrogen concentration in effluent did not exceed $6 \mathrm{mg} / \mathrm{L}$ (Figure 9), and nitrites and nitrates were the main nitrogen oxide form. The effluent $\mathrm{NO}_{3}{ }^{-}-\mathrm{N}$ and $\mathrm{NO}_{2}{ }^{-}-\mathrm{N}$ concentrations gradually increased. In the stable stage, the accumulated $\mathrm{NO}_{3}{ }^{-}-\mathrm{N}$ and $\mathrm{NO}_{2}{ }^{-}-\mathrm{N}$ concentrations increased up to $18.97,18.60,18.19$, and $18.88 \mathrm{mg} / \mathrm{L}$ at DO concentrations of $0.5-1$, $1-2,2-2.5$, and $2.5-3.5 \mathrm{mg} / \mathrm{L}$, respectively. As can be seen in Figure 9, the effluent $\mathrm{NH}_{4}-\mathrm{N}^{+}$(average $3.61 \mathrm{mg} / \mathrm{L})$ concentration at a DO of $2-2.5 \mathrm{mg} / \mathrm{L}$ was lower than when the DO was $0.5-1(4.58 \mathrm{mg} / \mathrm{L})$, $1-2(4.29 \mathrm{mg} / \mathrm{L})$, and $2.5-3.5 \mathrm{mg} / \mathrm{L}(3.84 \mathrm{mg} / \mathrm{L})$. In this experiment, the ammonia oxidation efficiency exceeded $81 \%$ with nitrites and nitrates as the main products. The treatment performance was the best when the DO was $2-2.5 \mathrm{mg} / \mathrm{L}$.

As the test site was located in Nyingtri in Tibet, the atmospheric pressure of Nyingtri was $706 \mathrm{hPa}$ (measured value). The oxygen content at $3000 \mathrm{~m}$ above sea level (ASL) was only $79 \%$ of that at sea level. Therefore, the calculation method should be revised according to the actual situation when the sewage treatment plant calculates the aeration amount $[35,36]$.

\subsection{The Relationship among the Changes of Pollutants, Microbial Community Structure, and Species Diversity}

The treatment performance can be explained by the relative OTU richness and evenness of microbial communities of activated sludge $[19,27]$. The community richness and evenness were two important factors that influenced the functional stability and general performance of WWTPs [37]. As Wittebolle [38] reported, communities with higher evenness have more functional resistance to environmental stress. According to Werner [39], in full-scale bioenergy systems, the methanogenic activity and substrate removal efficiency are correlated with community evenness. As shown in Figures 2-4, the highest OTU richness and evenness of microbial communities was observed when the COD/N ratio was 7:1 or the DO was $2-2.5 \mathrm{mg} / \mathrm{L}$. As shown in Table 3, the highest species diversity and evenness were also observed when the COD/N ratio was $7: 1$ or the $\mathrm{DO}$ was $2-2.5 \mathrm{mg} / \mathrm{L}$. The treatment performance was the best of the four conditions studied when the COD/N ratio was 7:1 or the DO was $2-2.5 \mathrm{mg} / \mathrm{L}$ (Figures 8 and 9). The shifts in microbial community with different operational conditions could be correlated with differential treatment performances. The treatment performance was the best when the COD/ $\mathrm{N}$ ratio was $7: 1$ or the $\mathrm{DO}$ was $2-2.5 \mathrm{mg} / \mathrm{L}$ because the relative OTU richness and evenness were the highest at these values. The richness and evenness of the community may be important for determining the general performance of WWTPs.

\section{Conclusions}

In this study, we proved that the wastewater treatment performance was the most efficient when the COD/N ratio was 7:1 (average $81 \%$ COD and $66 \%$ TP removal efficiency) or the DO was $2-2.5 \mathrm{mg} / \mathrm{L}$ (average $83 \%$ COD and 75\% TP removal efficiency) of the four different COD/N ratios (4:1, 5:1, 7:1, and 10:1) and DO concentrations $(0.5-1,1-2,2-2.5$, and $2.5-3.5 \mathrm{mg} / \mathrm{L})$ tested in a plateau region. The ammonia oxidation efficiency exceeded $89 \%$ for different COD/N ratios or $81 \%$ for different DO concentrations with nitrites and nitrates as the main products. We also demonstrated that the relative abundance species evenness of the microbial community structure of activated sludge was the greatest when the COD/ $\mathrm{N}$ ratio was $7: 1$ or the $\mathrm{DO}$ was $2-2.5 \mathrm{mg} / \mathrm{L}$. The microbial community structure was shown to vary with different $\mathrm{COD} / \mathrm{N}$ ratios or $\mathrm{DO}$ concentrations. Due to the difference in altitude between plateaus and plains, the calculation method of aeration in the sewage treatment plant should be adapted according to the actual situation. The analyses provided a better understanding of sewage treatment with different $\mathrm{COD} / \mathrm{N}$ ratios or $\mathrm{DO}$ concentrations in plateau areas.

Author Contributions: Conceptualization, J.X.; data curation, J.X.; formal analysis, J.X.; investigation, J.X. and L.N.; methodology, J.X.; project administration, P.W. and Y.L.; resources, P.W. and Y.L.; supervision, P.W. and Y.L.; validation, J.X.; visualization, J.X.; writing—original draft, J.X.; writing-review and editing, J.X. and Z.X.

Funding: This research was funded by the National Natural Science Foundation of China (no. 51568059). 
Conflicts of Interest: The authors declare no conflict of interest. The founding sponsors had no role in the design of the study; in the collection, analyses, or interpretation of data; in the writing of the manuscript, and in the decision to publish the results.

\section{References}

1. Xu, J.; Wang, P.F.; Li, Y.; Niu, L.H. Performance and characterization of the microbial community structures in the activated sludge from wastewater treatment plant at high altitudes in Tibet of China. Desalin. Water. Treat. 2018, 106, 108-115. [CrossRef]

2. Yang, M.; Liu, X.C.; Zhang, Y. Analysis of bacterial community structures in two sewage treatment plants with different sludge properties and treatment performance by nested PCR-DGGE method. J. Environ. Sci. 2007, 19, 60-66.

3. Juanico, M.; Weinberg, H.; Soto, N. Process design of waste stabilization ponds at high altitude in Bolivia. Water Sci. Technol. 2000, 42, 307-313. [CrossRef]

4. Strauss, E.A.; Lamberti, G.A. Regulation of nitrification in aquatic sediments by organic carbon. Limnol. Oceanogr. 2000, 45, 1854-1859. [CrossRef]

5. Yun, Z.; Jung, Y.H.; Lim, B.R. The stability of nitrite nitrification with strong nitrogenous wastewater: Effects of organic concentration and microbial diversity. Water Sci. Technol. 2004, 49, 89-96. [CrossRef]

6. Sharma, R.; Gupta, S.K. Influence of chemical oxygen demand to total Kjeldahl nitrogen ratio and sludge age on nitrification of nitrogenous wastewater. Water Environ. Res. 2004, 76, 155-161. [CrossRef]

7. Luo, J.H.; Hao, T.W.; Wei, L. Impact of Influent COD/N Ratio on Disintegration of Aerobic Granular Sludge. Water Res. 2014, 62, 127-135. [CrossRef]

8. Gieseke, A.; Purkhold, U.; Wagner, M.; Amann, R.; Schramm, A. Community structure and activity dynamics of nitrifying bacteria in a phosphate-removing biofilm. Appl. Environ. Microbiol. 2001, 67, 1351-1362. [CrossRef]

9. Zielinska, M.; Bernat, K.; Cydzik-Kwiatkowsa, A.; Sobolewska, J.; Wojnowska-Baryla, I. Nitrogen removal from wastewater and bacterial diversity in activated sludge at different COD/N ratios or dissolved oxygen concentrations. J. Environ. Sci. 2012, 24, 990-998. [CrossRef]

10. Kapley, A.; Tolmare, A.; Purohit, H.J. Role of oxygen in the utilization of phenol by Pseudomonas CF600 in continuous culture. J. Microbiol. Biotechnol. 2001, 17, 801-804. [CrossRef]

11. Wells, G.F.; Park, H.D.; Yeung, C.H.; Eggleston, B.; Francis, C.A.; Criddle, C.S. Ammonia-oxidizing communities in a highly aerated full-scale activated sludge bioreactor: Betaproteobacterial dynamics and low relative abundance of Crenarchaea. Environ. Microbiol. 2009, 11, 2310-2328. [CrossRef]

12. Garrido, J.M.; van Benthum, W.A.J.; van Loosdrecht, M.C.M.; Heijnen, J.J. Influence of dissolved oxygen concentration on nitrite accumulation in a biofilm airlift suspension reactor. Biotechnol Bioeng. 1997, 53, 168-178. [CrossRef]

13. Ganigué, R.; López, H.; Balaguer, M.D.; Colprim, J. Partial ammonium oxidation to nitrite of high ammonium content urban landfill leachates. Water Res. 2007, 41, 3317-3326. [CrossRef] [PubMed]

14. Pollice, A.; Tandoi, V.; Lestingi, C. Influence of aeration and sludge retention time on ammonium oxidation to nitrite and nitrate. Water Res. 2002, 36, 2541-2546. [CrossRef]

15. Ma, Y.; Peng, Y.Z.; Wang, S.Y.; Yuan, Z.G.; Wang, X.L. Achieving nitrogen removal via nitrite in a pilot-scale continuous pre-denitrification plant. Water Res. 2009, 43, 563-572. [CrossRef]

16. Chandra Yadav, T.; Khardenavis, A.A.; Kapley, A. Shifts in microbial community in response to dissolved oxygen Levels in activated sludge. Bioresour. Technol. 2014, 165, 257-264. [CrossRef] [PubMed]

17. The State Environmental Protection Administration. Water and Wastewater Monitoring Analysis Method, 4th ed.; China Environmental Science Press: Beijing, China, 2002. (In Chinese)

18. Xu, J.; Li, S.W. The Changes of Pollutants and Microbial Community Structures of the Activated Sludge in Response to Different Temperature Levels in Tibet of China. IOP Conf. Ser. Earth Environ. Sci. 2018, 189, 052080. [CrossRef]

19. Xu, J.; Wang, P.F.; Li, Y.; Niu, L.H. Activated sludge culture domestication at high altitudes in Tibet of China. Desalin. Water. Treat. 2019, 142, 98-103. [CrossRef]

20. Zhang, T.; Shao, M.F.; Ye, L. 454 pyrosequencing reveals bacterial diversity of activated sludge from 14 sewage treatment plants. ISME J. 2012, 6, 1137-1147. [CrossRef] 
21. Xia, S.; Duan, L.; Song, Y.; Li, J.; Piceno, Y.M.; Andersen, G.L.; Alvarez-Cohen, L.; Moreno-Andrade, I.; Huang, C.L.; Hermanowicz, S.W. Bacterial community structure in geographically distributed biological wastewater treatment reactors. Environ Sci. Technol. 2010, 44, 7391-7396. [CrossRef] [PubMed]

22. Flint, H.J.; Scott, K.P.; Duncan, S.H.; Louis, P.; Forano, E. Microbial degradation of complex carbohydrates in the gut. Gut Microbes 2010, 3, 289-306. [CrossRef]

23. Větrovský, T.; Steffen, K.T.; Baldrian, P. Potential of cometabolic transformation of polysaccharides and lignin in lignocellulose by soil actinobacteria. PLoS ONE 2014, 9, 1-9.

24. Gao, F.; Nan, J.; Zhang, X.H.; Wu, T.H. A dynamic modelling of nutrient metabolism in a cyclic activated sludge technology (CAST) for treating low carbon source wastewater. Environ. Sci. Pollut. Res. 2017, 24, 17016-17030. [CrossRef] [PubMed]

25. LeCleir, G.R.; Buchan, A.; Hollibaugh, J.T. Chitinase gene sequences retrieved from diverse aquatic habitats reveal environment-specific distributions. Appl. Environ. Microbiol. 2004, 70, 6977-6983. [CrossRef]

26. Zang, K.; Kurisu, F.; Kasuga, I.; Furumai, H.; Yagi, O. Analysis of the phylogenetic diversity of estrone-degrading bacteria in activated sewage sludge using microautoradiography-fluorescence in situ hybridization. Syst. Appl. Microbiol. 2008, 31, 206-214. [CrossRef] [PubMed]

27. Niu, L.H.; Li, Y.; Wang, P.F. Understanding the linkage between elevation and activated sludge bacterial community along a $3600 \mathrm{~m}$ elevational gradient in China. Appl. Environ. Microbiol. 2015, 81, 6567-6576. [CrossRef] [PubMed]

28. Ryu, H.D.; Lee, S.I. Comparison of 4-stage biological aerated filter (BAF) with MLE process in nitrogen removal from low carbon-to-nitrogen wastewater. Environ. Eng. Sci. 2009, 26, 163-170. [CrossRef]

29. Her, J.J.; Huang, J.S. Influences of carbon source and $\mathrm{C} / \mathrm{N}$ ratio on nitrate/nitrite denitrification and carbon breakthrough. Bioresour. Technol. 1995, 54, 45-51. [CrossRef]

30. Liu, H.B.; Yang, C.Z.; Pu, W.H. Removal of nitrogen from wastewater for reusing to boiler feed-water by an anaerobic/aerobic/membrane bioreactor. Chem. Eng. J. 2008, 140, 122-129. [CrossRef]

31. Sheng, P.S.; Carles, P.N.; Brian, M. Effective Biological Nitrogen Removal Treatment Processes for Domestic Wastewaters with Low C/N Ratios: A Review. Environ. Eng. Sci. 2010, 27, 111-126.

32. Puigagut, J.; Salvadó, H.; García, J. Short-term harmful effects of ammonia nitrogen on activated sludge microfauna. Water Res. 2005, 39, 4397-4404. [CrossRef]

33. Khardenavis, A.A.; Kapley, A.; Purohit, H.J. Simultaneous nitrification and denitrification by diverse Diaphorobacter sp. Appl. Microbiol. Biotechnol. 2007, 77, 403-409. [CrossRef] [PubMed]

34. Rajagopal, R.; Massé, D.I.; Singh, G. A critical review on inhibition of anaerobic digestion process by excess ammonia. Bioresour. Technol. 2013, 143, 632-641. [CrossRef]

35. Shen, H.Y.; Guo, Y.; Wang, Y.Y.; Shen, Y.T. Case study on engineering projects of sewage treatment plants in plateau region. Water. Pure Technol. 2014, 33, 9-12. (In Chinese)

36. Cui, J. Discussion on the calculation of air supply for sewage treatment plant in plateau region. Water Wastewater Eng. 2012, 38, 41-45. (In Chinese)

37. Johnson, D.R.; Lee, T.K.; Park, J.; Fenner, K.; Helbling, D.E. The functional and taxonomic richness of wastewater treatment plant microbial communities are associated with each other and with ambient nitrogen and carbon availability. Environ. Microbiol. 2015, 17, 4851-4860. [CrossRef]

38. Wittebolle, L.; Marzorati, M.; Clement, L.; Balloi, A.; Daffonchio, D.; Heylen, K.; De Vos, P.; Verstraete, W.; Boon, N. Initial community evenness favours functionality under selective stress. Nature 2009, 458, 623-626. [CrossRef] [PubMed]

39. Werner, J.J.; Knights, D.; Garcia, M.L.; Scalfone, N.B.; Smith, S.; Yarasheski, K.; Cummings, T.A.; Beers, A.R.; Knight, R.; Angenent, L.T. Bacterial community structures are unique and resilient in full-scale bioenergy systems. Proc. Natl. Acad. Sci. USA 2011, 108, 4158-4163. [CrossRef]

(C) 2019 by the authors. Licensee MDPI, Basel, Switzerland. This article is an open access article distributed under the terms and conditions of the Creative Commons Attribution (CC BY) license (http://creativecommons.org/licenses/by/4.0/). 